\title{
Uitspraken over tuchtrechtelijke aansprakelijkheid voor schadeafwikkeling door aansprakelijkheidsverzekeraars (m.nt. van mr. F.M. Ruitenbeek-Bart)
}

\section{RTG Amsterdam, 4 juli 2017, eerste zaak}

Regionaal Tuchtcollege voor de Gezondheidszorg Amsterdam 4 juli 2017 (mr. E.A. Messer, dr. B. van Ramshorst, dr. W.J. Willems en drs. J.C. van der Molen, mr.dr. A. Wilken), zaaknr. 2016/346, ECLI:NL:TGZRAMS:2017:77, A tegen $C$, orthopeed te $D$

\section{De procedure}

Het college heeft kennisgenomen van:

- het klaagschrift;

- het verweerschrift met de bijlagen;

- de correspondentie met betrekking tot het vooronderzoek;

- de op 12 januari 2017 binnengekomen brief van klaagster;

- de op 24 januari 2017 door klaagster toegezonden uitspraak Klachtencommissie EMS d.d. 9 oktober 2015;

- de op 14 maart 2017 binnengekomen brief van klaagster;

- de op 20 april 2017 binnengekomen brief met bijlagen van mr. Berkhoff-Muntinga;

- de op 25 april 2017 binnengekomen brief met bijlage van klaagster

Partijen hebben geen gebruik gemaakt van de hun geboden mogelijkheid in het kader van het vooronderzoek mondeling te worden gehoord.

De klacht is op de openbare zitting van 31 januari 2017 gezamenlijk en gelijktijdig behandeld met de klacht in de zaak 16/345 op de voet van artikel 57 lid 1 van de Wet op de Beroepen in de Individuele Gezondheidszorg (BIG).
Partijen waren aanwezig. Klaagster heeft haar echtgenote gemachtigd om namens haar het woord te voeren. Verweerder werd bijgestaan door zijn gemachtigde, mr. Berkhoff-Muntinga voornoemd.

Ter zitting is in overleg met partijen afgesproken dat de zaak tot een nader te bepalen moment zou worden aangehouden teneinde partijen in de gelegenheid te stellen een minnelijke regeling te bereiken. $\mathrm{Nu}$ partijen echter geen minnelijke regeling hebben getroffen, is de mondelinge behandeling op de openbare zitting 19 mei 2017 voorgezet. Partijen waren aanwezig. Klaagster werd vergezeld door haar echtgenoot. Verweerder werd bijgestaan door zijn gemachtigde, mr. Berkhoff-Muntinga voornoemd.

\section{De feiten}

2.1 Verweerder is sinds 2013 als orthopedisch-chirurg werkzaam bij E te D. Zijn aandachtsgebieden zijn traumatologie, voet- en enkelchirurgie, heupprothesiologie en chirurgie van het kniegewricht.

2.2 Klaagster was sinds enige tijd bij een collega van verweerder in behandeling in verband met (pijn)klachten aan haar linkervoet. Op 16 mei 2014 heeft klaagster een operatie ondergaan aan deze voet. De operatie is uitgevoerd door verweerder als eerste operateur en voornoemde collega als tweede operateur. De operatie is uitgevoerd in het F te G waar door E operatieruimte (met bijbehorend personeel en materiaal) werd gehuurd. Klaagster had zowel verweerder als zijn collega eerder ontmoet tijdens aan de operatie voorafgaande poliklinische bezoeken. 
2.3 Tijdens de operatie werden overtollig botweefsel en twee eerder ingebrachte schroeven uit het TMT-I gewricht verwijderd bij een status na TMT-I arthrodese en hypertrofische callusvorming. Om het overtollige botweefsel te verwijderen werd bij de operatie gebruik gemaakt van een oscillerende zaag van het merk H. Deze zaag was beschikbaar gesteld door het F. Zowel verweerder als zijn collega hebben de zaag tijdens de operatie gehanteerd.

2.4 Op een bepaald moment tijdens de operatie heeft verweerder of zijn collega de zaag op het linker bovenbeen van klaagster gelegd. In verband met een technisch mankement is de zaag oververhit geraakt als gevolg waarvan er een derdegraads brandwond op het been van klaagster is ontstaan. Nadat dit was opgemerkt en de zaag van het bovenbeen van klaagster was verwijderd, is de brandwond direct gekoeld en heeft een aan het $G$ verbonden plastisch chirurg de behandeling van de brandwond verder op zich genomen.

2.5 Verweerder en zijn collega hebben klaagster en haar partner op de verkoeverkamer op de hoogte gebracht van het incident. Op verzoek van klaagster is de verdere behandeling van de brandwond overgedragen aan de afdeling plastische chirurgie van het I te B. In juni 2014 is klaagster behandeld en geopereerd in het $\mathrm{J}$ te $\mathrm{K}$ en in april 2016 heeft nogmaals een hersteloperatie van het litteken plaatsgevonden in het I te B.

2.6 Zowel verweerder als zijn collega waren voor de operatie op 16 mei 2014 niet op de hoogte van de inhoud van de bij de zaag behorende gebruiksaanwijzing. Deze gebruiksaanwijzing bevat de volgende, hier relevante passages:

'Deze gebruiksaanwijzing verschaft de benodigde informatie voor het gebruik en onderhoud van H DYONICS elektrische instrumenten. Het is belangrijk dat $u$ alle informatie in dit document voor gebruik of onderhoud van de apparatuur leest en begrijpt.'

\section{WAARSCHUWINGEN}

$\cdot(\ldots)$

- Deze instructies vóór gebruik geheel doorlezen.

$\cdot(\ldots)$

- Om brandwonden bij de patiënt te voorkomen, dient $u$ het elektrische instrument niet op de patiënt te plaatsen wanneer dit niet wordt gebruikt.

2.7 Naar aanleiding van dit incident is er een zogenoemde VIM-melding gedaan (Veilig Incident Melden) en is er een prisma-analyse op de situatie uitgevoerd. Daarnaast zijn er in verband met dit incident de nodige maatregelen genomen om zo veel als mogelijk te voorkomen dat dergelijke incidenten zich in de toekomst nogmaals voor kunnen doen. Zo is in het inwerkprogramma van de kliniek waar verweerder werkzaam is, opgenomen dat de handleidingen van te gebruiken medisch instrumentarium gelezen dienen te worden en dienen alle orthopedisch chirurgen van de kliniek de oscillerende zaag na elk gebruik af te koppelen en mag de zaag niet meer aangekoppeld op de patiënt worden gelegd. Verder heeft verweerder samen met zijn collega een wetenschappelijk artikel geschreven waarin wordt gewezen op het gevaar dat gepaard gaat met het leggen van een (aangekoppelde) oscillerende zaag op een patiënt (hetgeen volgens verweerder en zijn collega een gebruikelijke praktijk is). Dit artikel is tot op heden nog niet gepubliceerd.

2.8 Op 28 mei 2014 heeft klaagster in verband met poliklinische nacontrole het spreekuur van de collega van verweerder bezocht en op 4 juni 2014 heeft zij het spreekuur van verweerder bezocht

2.9 Klaagster heeft naar aanleiding van het incident een klacht ingediend bij de C waarbij (de kliniek van) verweerder is aangesloten. Deze klacht is - ten aanzien van het ontstaan van de brandwond gegrond verklaard.

2.10 Verder heeft klaagster kort na het incident zowel verweerder (en zijn collega) als het $\mathrm{F}$ en de producent van de zaag aansprakelijk gesteld voor de door haar geleden materiele en immateriële schade. Verweerder (en zijn collega) wordt in deze kwestie namens zijn aansprakelijkheidsverzekeraar bijge- 
staan door M. Aansprakelijkheid van verweerder (en zijn collega) is in eerste instantie van de hand gewezen omdat de aansprakelijkheid zou berusten bij $\mathrm{H}$ als producent van de zaag en/of het $\mathrm{F}$ als bezitter/ eigenaar van de zaag. Dit was voor klaagster reden om de onderhavige tuchtprocedure te starten.

$2.11 \mathrm{Na}$ de openbare terechtzitting van 31 januari 2017 - waarin de verdere behandeling van de tuchtklacht is aangehouden in afwachting van een eventuele minnelijke regeling - is op 3 februari 2017 door $\mathrm{M}$ namens verweerder (en zijn collega) alsnog aansprakelijkheid erkend voor de door klaagster als gevolg van de brandwond geleden schade.

2.12 Vervolgens is er tussen klaagster (en haar belangenbehartiger) en $\mathrm{M}$ (opnieuw) discussie ontstaan over de hoogte van de schade. Klaagster heeft zich in een (emotioneel) e-mailbericht van 24 februari 2017 tot (onder meer) verweerder gewend en aandacht gevraagd voor haar lichamelijke, emotionele en financiële problemen als gevolg van het incident. In dit bericht heeft zij aangedrongen op een spoedige financiële afwikkeling nu aansprakelijkheid is erkend. In zijn reactie van 26 februari 2017 schrijft verweerder (mede namens zijn collega):

'Uw email van 24 februari jl. heeftN en mij bereikt en heeft grote indruk gemaakt. Naar aanleiding van uw email zijn wij een standpunt aan het formuleren betreffende de, in onze ogen incorrecte, werkwijze van de $\mathrm{M}$ in deze. Mogelijk kan dat $\mathrm{u}$ helpen om het, door $\mathrm{u}$ gewenste, doel te bereiken van een reële schadevergoeding (en daarmee uiteraard ook het intrekken van uw klacht tegen ons bij het tuchtcollege).

Wij willen dit standpunt echter eerst voorleggen aan mijn raadsvrouwe (mr. Berkhoff), zij is echter $\mathrm{t} / \mathrm{m} 3$ maart afwezig en verzoekt $\mathrm{u}$ derhalve ons tot 10 maart de tijd te geven dit af te ronden en met $u$ te delen.'

In een vervolgbericht van 10 maart 2017 schrijft verweerder:
'In ons mailbericht van 26 februari zegden wij $\mathrm{u}$ toe om $\mathfrak{u}$ voor 10 maart nog een bericht te sturen.

Wij hebben inmiddels vernomen dat $\mathrm{M}$ een aanbod heeft gedaan richting uw gemachtigde. Omdat wij geen partij zijn in de onderhandelingen tussen $\mathrm{M}$ en uw gemachtigde kunnen wij daar verder ook geen uitspraak over doen. Uiteraard hopen wij van harte dat jullie tot overeenstemming kunnen komen en dat $\mathrm{u}$ daarmee deze vreselijke periode uit uw leven kunt afsluiten. Ook wij zullen het gebeuren levenslang met ons meedragen.'

2.13 Ten tijde van de (voortgezette) behandeling op de openbare zitting van 19 mei 2017 was de civiele aansprakelijkheidskwestie nog niet afgewikkeld.

\section{De klacht en het standpunt van klaagster}

De klacht houdt zakelijk weergegeven in dat verweerder onzorgvuldig heeft gehandeld door:

(i) de oscillerende zaag in strijd met de gebruiksaanwijzing tijdens de operatie op het bovenbeen van klaagster neer te leggen, als gevolg waarvan een ernstige brandwond is ontstaan;

(ii) na het incident geen contact met klaagster op te nemen om te informeren naar haar toestand; en

(iii) aansprakelijkheid van de hand te wijzen en de fabrikant aan te wijzen als schuldige.

\section{Het standpunt van verweerder}

Verweerder heeft zich primair beroepen op de nietontvankelijkheid van klaagster omdat - nu op 3 februari 2017 alsnog (civiele) aansprakelijkheid is erkend - sprake zou zijn van oneigenlijk gebruik van de tuchtprocedure en subsidiair de klacht en de daaraan ten grondslag gelegde stellingen bestreden. Voor zover nodig wordt daarop hieronder ingegaan. 


\section{De beoordeling}

\section{Ontvankelijkheid}

5.1. Het College verwerpt het beroep van verweerder op de niet-ontvankelijkheid van klaagster in haar klacht. Het feit dat aansprakelijkheid voor het handelen van verweerder (en zijn collega) voor de door klaagster als gevolg van de brandwond geleden schade inmiddels is erkend, betekent geenszins dat door het desondanks voortzetten van de onderhavige tuchtprocedure, sprake zou zijn van oneigenlijk gebruik van de tuchtprocedure. Het College heeft zich - in het licht van het feit dat de onderhavige tuchtprocedure kennelijk nodig was om erkenning van aansprakelijkheid af te kunnen dwingen ook enigszins over dit verweer verbaasd. Het staat klaagster vrij om het handelen van verweerder ter tuchtrechtelijke toetsing aan het College voor te leggen. Een eventueel civiel aansprakelijkheidstraject (en het verloop daarvan) doet daar niet aan af. Daarom zal nu inhoudelijk op de klachtonderdelen worden ingegaan.

\section{Klachtonderdeel 1}

5.2. Met betrekking tot het gebruik van de oscillerende zaag staat vast dat de gebruiksaanwijzing van deze zaag het voorschrift bevat dat de zaag niet op de patiënt mag worden geplaatst om brandwonden bij de patiënt te voorkomen. In dat kader acht het College het niet zo relevant of het een in de orthopedische praktijk al dan niet gebruikelijke gang van zaken is dat een dergelijke zaag - ondanks dat deze kan worden afgekoppeld - in het operatiegebied (op operatietafel of op de (afgedekte) patiënt) wordt gelegd als deze gedurende de operatie even niet wordt gebruikt, maar daarna nog wel nodig is. Als een dergelijke gang van zaken al gebruikelijk zou zijn, moet op basis van voornoemde gebruiksaanwijzing worden vastgesteld dat dit een onjuiste gang van zaken is die aanzienlijke risico's voor patiënten met zich meebrengt, welke risico's zich ten aanzien van klaagster helaas ook hebben verwezenlijkt.

5.3 Dat het in de praktijk kennelijk niet gebruikelijk is dat de gebruiksaanwijzing van dit soort 'simpele' apparaten wordt gelezen, zoals verweerder naar voren heeft gebracht, wil niet zeggen dat verweerder in dit kader dus geen tuchtrechtelijk verwijt kan worden gemaakt. Als artsen gebruik maken van technische hulpmiddelen, behoren zij zich te vergewissen van de werking van deze hulpmiddelen en eventuele daaraan verbonden risico's / gevaren, bijvoorbeeld door het lezen van de gebruikershandleiding van dergelijke hulpmiddelen. Anders dan verweerder heeft betoogd, mogen artsen daarbij niet enkel varen op hetgeen zij tijdens hun opleiding hebben geleerd over het gebruik van dergelijke apparaten. De tijdens de opleiding opgedane kennis kan in de praktijk zijn verouderd en - zoals de onderhavige zaak illustreert - kan een in de opleiding aangeleerde werkwijze bovendien in strijd zijn met de aan het gebruik van een technisch hulpmiddel verbonden veiligheidsvoorschriften.

5.4 Door de oscillerende zaag in strijd met de gebruiksaanwijzing op het been van klaagster te leggen, heeft verweerder in strijd gehandeld met de van hem ten opzichte van klaagster te verwachten zorgvuldigheid.

\section{Klachtonderdeel 2}

$5.5 \mathrm{Na}$ een ernstig incident als het onderhavige is het van belang dat hier door de betrokken zorgverleners adequaat op wordt gereageerd en voldoende nazorg wordt geboden. In dit kader kan worden gewezen op de sinds 2010 geldende Gedragscode Openheid medische incidenten; betere afwikkeling Medische Aansprakelijkheid (GOMA) waarin onder meer is opgenomen dat als er zich een incident heeft voorgedaan met (mogelijke) gevolgen voor de patiënt, zo snel mogelijk contact wordt opgenomen met de patiënt (Aanbeveling 3), er wordt ondernomen wat nodig is om de negatieve gevolgen van het incident voor de gezondheidssituatie weg te nemen of te beperken (Aanbeveling 4), wordt onderzocht hoe het incident heeft kunnen ontstaan en activiteiten worden ondernemen die nodig zijn om te voorkomen dat het incident zich nog eens voordoet (Aanbeveling 5) en als blijkt dat er sprake is van een fout, die door de betreffende zorgaanbieder / zorgverle- 
ner(s) wordt erkend en daarvoor verontschuldigingen worden aangeboden. Deze uitgangspunten zijn - weliswaar in iets andere bewoordingen - sinds 1 januari 2016 ook vastgelegd in artikel 10 lid 3 van de Wet kwaliteit, klachten en geschillen zorg (Wkkgz).

5.6 Door direct na het incident de aanwezige plastisch chirurg in consult te roepen (die de behandeling van de brandwond in eerste instantie verder op zich genomen heeft) en klaagster en haar partner op de verkoeverkamer direct op de hoogte te brengen van het incident en daarvoor excuses te maken, heeft verweerder in beginsel adequaat op het incident gereageerd (zie hierna ook de beoordeling van klachtonderdeel 3). Door bovendien maatregelen te treffen om zo veel als mogelijk te voorkomen dat dergelijke incidenten zich in de toekomst nogmaals voor kunnen doen, hierover een wetenschappelijk artikel te schrijven en regelmatig - onder andere bij zijn nieuwe werkgever - voorlichting te geven over het gevaar dat gepaard gaat met het leggen van een (aangekoppelde) technische hulpmiddelen op een patiënt, heeft verweerder zich ook in dat kader ruimschoots voldoende ingespannen.

5.7 Klaagster verwijt verweerder weliswaar dat hij na het incident geen contact meer met haar heeft opgenomen om te informeren naar haar (gezondheids)toestand, maar klaagster heeft niet bestreden dat er na het incident wel degelijk een aantal maal contact met verweerder (en zijn collega) is geweest, onder andere in de vorm van poliklinische controleafspraken. Het College acht het voor de hand liggend dat er op die momenten door verweerder (en zijn collega) ook naar de gezondheidstoestand van klaagster is geïnformeerd. $\mathrm{Nu}$ verdere behandeling van zowel de brandwond als de linkervoet op verzoek van klaagster elders heeft plaatsgevonden, kon niet van verweerder worden verwacht dat hij ook na beëindiging van de behandeling nog actief contact met verweerster zou zoeken. Er is ook niet gebleken dat klaagster aan verweerder heeft laten weten daar behoefte aan te hebben. Het tweede klachtonderdeel is derhalve ongegrond.

\section{Klachtonderdeel 3}

5.8 Tot slot verwijt klaagster verweerder dat hij aansprakelijkheid van de hand bleef wijzen en de fabrikant aanwijst als schuldige. Aan verweerder kan worden toegegeven dat de beoordeling van de (civielrechtelijke) aansprakelijkheid (over het algemeen) namens de zorgaanbieder door zijn aansprakelijkheidsverzekeraar wordt uitgevoerd, en zorgverleners zich in die verhouding niet behoren uit te laten over aansprakelijkheid. De erkenning van aansprakelijkheid staat echter niet gelijk aan het erkennen van een fout (welk onderscheid voor klaagster begrijpelijkerwijs moeilijk te maken is), hetgeen juist wel tot het domein van de zorgverlener behoort.

5.9 Verweerder (en zijn collega) hebben na het incident weliswaar hun excuses aangeboden, maar zoals verweerder ter zitting nogmaals heeft bevestigd, vindt hij ondanks dat aansprakelijkheid inmiddels is erkend, nog steeds dat hij geen fout heeft gemaakt en het incident te wijten is aan het technisch mankement in de oscillerende zaag. Nu het in strijd met de gebruiksaanwijzing hanteren van een oscillerende zaag als gevolg waarvan er een ernstige brandwond bij klaagster is ontstaan, naar het oordeel van het College echter moeilijk anders gekwalificeerd kan worden dan als een fout, had het op de weg van verweerder gelegen deze fout ten opzichte van verweerster ook toe te geven. Nu de klacht van verweerster echter betrekking lijkt te hebben op de erkenning van de aansprakelijkheid in het kader van de civiele schadeafwikkeling - het domein van de aansprakelijkheidsverzekeraar - kan verweerder hiervan tuchtrechtelijk geen verwijt worden gemaakt.

5.10 Het standpunt van (de gemachtigde van) verweerder dat verweerder niet betrokken is geweest bij het civiele aansprakelijkheidstraject en de discussie daaromtrent, en hem daarvan derhalve geen enkel verwijt kan worden gemaakt, acht het College in zijn algemeenheid overigens niet juist. Als een zorgverlener een fout maakt - of een dergelijke fout door een patiënt wordt gesteld - laat de zorgverlener de civiele schadeafwikkeling van die fout door- 
gaans over aan zijn aansprakelijkheidsverzekeraar. Dit brengt naar het oordeel van het College echter niet mee dat de zorgverlener daarmee ook geen enkele verantwoordelijkheid meer zou dragen voor de manier waarop die schadeafwikkeling verloopt.

5.11 Ondanks dat het College niet over alle informatie met betrekking tot de civiele schadeafwikkeling in deze zaak beschikt, is zij er op basis van de beschikbare informatie en de verklaringen van partijen ter zitting voldoende van overtuigd geraakt dat de schadeafwikkeling in deze zaak door M niet op zorgvuldige wijze plaatsvindt. Illustratief hiervoor is dat de onderhavige tuchtprocedure noodzakelijk was om erkenning van aansprakelijkheid af te dwingen en - desondanks - door M, naast een (lang voor deze tuchtprocedure) reeds betaald voorschot, nog geen aanvullend voorschot / aanvullende schadevergoeding is uitgekeerd, in ieder geval tot het bedrag waarover tussen partijen geen discussie bestaat. Het uitblijven daarvan lijkt mede het gevolg te zijn van een discussie tussen de belangenbehartiger van klaagster en $\mathrm{M}$ over de buitengerechtelijke kosten (waar klaagster in principe buiten staat). De handelwijze van $\mathrm{M}$ is op verschillende punten in strijd met de aanbevelingen in de GOMA omtrent een adequate afhandeling van verzoeken om schadevergoeding. Bovendien spreekt ook verweerder in zijn bericht aan klaagster van 26 februari 2017 van een in zijn ogen incorrecte werkwijze van M. Dit in civiele medische aansprakelijkheidszaken niet onbekende verschijnsel dat het patiënten onevenredig veel tijd, vechtlust, geld en aandacht kost om hun schade vergoed te kunnen krijgen (hetgeen lang niet ieder slachtoffer van een medische fout op kan brengen), acht het College verwerpelijk.

5.12 De zorgvuldigheid die een zorgverlener op grond van artikel 47 lid 1 Wet BIG jegens de patiënt moet betrachten, omvat eveneens de manier waarop de zorgverlener na een (gestelde) medische fout met de patiënt omgaat. Als er zich in het kader van de zorgverlening een incident voordoet, is communicatie, persoonlijke aandacht, empathie, zorgzaamheid en correcte bejegening van groot belang. Niet valt in te zien waarom dit voor de financiële afwikkeling van een (verwijtbaar) incident anders zou zijn dan voor de medische afwikkeling daarvan. Ook niet als de financiële gevolgen namens de zorgverlener worden afgewikkeld door een aansprakelijkheidsverzekeraar. Op het moment dat een aansprakelijkheidsverzekeraar de schade op onzorgvuldige wijze afwikkelt (waarvan op basis van wetenschappelijk onderzoek inmiddels voldoende vaststaat dat dit een negatieve invloed heeft op het welzijn van patiënten), ligt het op de weg van de arts (wiens doel juist het bevorderen van het welzijn van patiënten zou moeten zijn) zijn verzekeraar daarop aan te spreken. De aansprakelijkheidsverzekeraar zal op basis van de verzekeringsovereenkomst jegens de arts immers verplicht zijn de schadeafwikkeling namens de arts op correcte wijze uit te voeren. Blijkens zijn bericht aan klaagster van 26 februari 2017 (zie hiervoor onder 2.12), heeft verweerder $\mathrm{N}$ na aanvang van de onderhavige tuchtprocedure wel op de in zijn ogen incorrecte werkwijze aangesproken. Het is echter onduidelijk of dit enig effect heeft gehad en bovendien had het op de weg van verweerder gelegen dat (veel) eerder te doen.

$5.13 \mathrm{Nu}$ het College met het voorgaande een vrij ruime uitleg heeft gegeven aan het derde klachtonderdeel - en de daarin vervatte norm, dat een hulpverlener niet enkel verantwoordelijk is voor een correcte afwikkeling van de medische gevolgen maar ook voor de financiële gevolgen van zijn fout, onder artsen mogelijk (nog) niet voldoende bekend is acht het College het nalaten van verweerder om M (tijdig) aan te spreken op de incorrecte wijze waarop de schade van klaagster werd (en mogelijk nog steeds wordt) afgewikkeld, op dit moment en in deze situatie niet tuchtrechtelijk verwijtbaar. Ook het derde klachtonderdeel is daarmee ongegrond.

De conclusie van het voorgaande is dat de klacht deels gegrond is. Verweerder heeft gehandeld in strijd met de zorg die hij ingevolge artikel 47 lid 1 van de Wet op de beroepen in de individuele gezondheidszorg jegens klaagster had behoren te betrachten. 
Met betrekking tot de op te leggen maatregel overweegt het College dat verweerder zich ten tijde van het incident niet bewust was van het mogelijk onveilige karakter van de door de door hem gehanteerde werkwijze en hij bovendien meer dan gemiddeld lering heeft getrokken uit het incident. Bovendien is verweerder nooit eerder tuchtrechtelijk te verantwoording geroepen. Er kan derhalve worden volstaan met een waarschuwing.

Om redenen, aan het algemeen belang ontleend, zal de beslissing zodra zij onherroepelijk is op na te melden wijze worden bekendgemaakt.

\section{De beslissing}

Het college:

- verklaart klachtonderdeel klachtonderdeel 1 gegrond;

- legt aan verweerder de maatregel van waarschuwing op;

- $\quad$ wijst de klacht voor het overige af.

Bepaalt voorts dat de beslissing ingevolge artikel 71 van de Wet BIG in de Nederlandse Staatscourant zal worden bekendgemaakt en aan het Tijdschrift voor Gezondheidsrecht en Medisch Contact ter bekendmaking zal worden aangeboden.

\section{RTG Amsterdam, 4 juli 2017, tweede zaak}

Regionaal Tuchtcollege voor de Gezondheidszorg Amsterdam 4 juli 2017 (mr. E.A. Messer, dr. B. van Ramshorst, dr. W.J. Willems en drs. J.C. van der Molen, mr.dr. A. Wilken), zaaknr. 2016/345, ECLI:NL:TGZRAMS:2017:78, A tegen $\mathrm{C}$, orthopeed te $\mathrm{F}$

\section{De procedure}

Het college heeft kennisgenomen van:

- het klaagschrift;

- het verweerschrift;

- de correspondentie met betrekking tot het vooronderzoek;

- de op 12 januari 2017 binnengekomen brief van klaagster;
- de op 24 januari 2017 door klaagster toegezonden uitspraak Klachtencommissie EMS d.d. 9 oktober 2015;

- de op 14 maart 2017 binnengekomen brief van klaagster;

- de op 25 april 2017 binnengekomen brief met bijlage van klaagster

Partijen hebben geen gebruik gemaakt van de hun geboden mogelijkheid in het kader van het vooronderzoek mondeling te worden gehoord.

De klacht is op de openbare zitting van 31 januari 2017 gezamenlijk en gelijktijdig behandeld met de klacht in de zaak 16/346 op de voet van artikel 57 lid 1 van de Wet op de Beroepen in de Individuele Gezondheidszorg (BIG).

Partijen waren aanwezig. Klaagster heeft haar echtgenote gemachtigd om namens haar het woord te voeren.

Ter zitting is in overleg met partijen afgesproken dat de zaak tot een nader te bepalen moment zou worden aangehouden teneinde partijen in de gelegenheid te stellen een minnelijke regeling te bereiken.

$\mathrm{Nu}$ partijen echter geen minnelijke regeling hebben getroffen, is de mondelinge behandeling op de openbare zitting 19 mei 2017 voorgezet. Klaagster was aanwezig en werd vergezeld door haar echtgenoot. Verweerder was met kennisgeving afwezig. Hij werd ter zitting vertegenwoordigd door zijn collega $\mathrm{E}$ en diens gemachtigde mr. BerkhoffMuntinga.

\section{De feiten}

2.1 Verweerder is als orthopedisch-chirurg werkzaam bij $\mathrm{F}$ te $\mathrm{D}$ en maakt daar deel uit van de directie.

2.2 Klaagster was sinds enige tijd bij verweerder in behandeling in verband met (pijn)klachten aan haar linkervoet. Op 16 mei 2014 heeft klaagster een operatie ondergaan aan deze voet. De operatie is uitgevoerd door een collega van verweerder als eerste operateur en verweerder als tweede operateur. De operatie is uitgevoerd in het $\mathrm{G}$ te $\mathrm{H}$ waar door F ope- 
ratieruimte (met bijbehorend personeel en materiaal) werd gehuurd. Klaagster had zowel verweerder als zijn collega eerder ontmoet tijdens aan de operatie voorafgaande poliklinische bezoeken.

2.3 Tijdens de operatie werden overtollig botweefsel en twee eerder ingebrachte schroeven uit het TMT-I gewricht verwijderd bij een status na TMT-I arthrodese en hypertrofische callusvorming. Om het overtollige botweefsel te verwijderen werd bij de operatie gebruik gemaakt van een oscillerende zaag van het merk I. Deze zaag was beschikbaar gesteld door het J. Zowel verweerder als zijn collega hebben de zaag tijdens de operatie gehanteerd.

2.4 Op een bepaald moment tijdens de operatie heeft verweerder of zijn collega de zaag op het linker bovenbeen van klaagster gelegd. In verband met een technisch mankement is de zaag oververhit geraakt als gevolg waarvan er een derdegraads brandwond op het been van klaagster is ontstaan. Nadat dit was opgemerkt en de zaag van het bovenbeen van klaagster was verwijderd, is de brandwond direct gekoeld en heeft een aan het $G$ verbonden plastisch chirurg de behandeling van de brandwond verder op zich genomen.

2.5 Verweerder en zijn collega hebben klaagster en haar partner op de verkoeverkamer op de hoogte gebracht van het incident. Op verzoek van klaagster is de verdere behandeling van de brandwond overgedragen aan de afdeling plastische chirurgie van het J te B. In juni 2014 is klaagster behandeld en geopereerd in het $\mathrm{K}$ te $\mathrm{L}$ en in april 2016 heeft nogmaals een hersteloperatie van het litteken plaatsgevonden in het J te B.

2.6 Zowel verweerder als zijn collega waren voor de operatie op 16 mei 2014 niet op de hoogte van de inhoud van de bij de zaag behorende gebruiksaanwijzing. Deze gebruiksaanwijzing bevat de volgende, hier relevante passages:

'Deze gebruiksaanwijzing verschaft de benodigde informatie voor het gebruik en onderhoud van I DYONICS elektrische instrumenten. Het is belangrijk dat $u$ alle informatie in dit document voor gebruik of onderhoud van de apparatuur leest en begrijpt.'

\section{WAARSCHUWINGEN}

$\cdot(\ldots)$

- Deze instructies vóór gebruik geheel doorlezen.

$\cdot(\ldots)$

- Om brandwonden bij de patiënt te voorkomen, dient $u$ het elektrische instrument niet op de patiënt te plaatsen wanneer dit niet wordt gebruikt.

2.7 Naar aanleiding van dit incident is er een zogenoemde VIM-melding gedaan (Veilig Incident Melden) en is er een prisma-analyse op de situatie uitgevoerd. Daarnaast zijn er in verband met dit incident de nodige maatregelen genomen om zo veel als mogelijk te voorkomen dat dergelijke incidenten zich in de toekomst nogmaals voor kunnen doen. $\mathrm{Zo}$ is in het inwerkprogramma van de kliniek van verweerder, opgenomen dat de handleidingen van te gebruiken medisch instrumentarium gelezen dienen te worden en dienen alle orthopedisch chirurgen van de kliniek de oscillerende zaag na elk gebruik af te koppelen en mag de zaag niet meer aangekoppeld op de patiënt worden gelegd. Verder heeft verweerder samen met zijn collega een wetenschappelijk artikel geschreven waarin wordt gewezen op het gevaar dat gepaard gaat met het leggen van een (aangekoppelde) oscillerende zaag op een patiënt (hetgeen volgens verweerder en zijn collega een gebruikelijke praktijk is). Dit artikel is tot op heden nog niet gepubliceerd.

2.8 Op 28 mei 2014 heeft klaagster in verband met poliklinische nacontrole het spreekuur van verweerder bezocht en op 4 juni 2014 heeft zij het spreekuur van de collega van verweerder bezocht.

2.9 Klaagster heeft naar aanleiding van het incident een klacht ingediend bij de M waarbij (de kliniek van) verweerder is aangesloten. Deze klacht is - ten aanzien van het ontstaan van de brandwond gegrond verklaard.

2.10 Verder heeft klaagster kort na het incident zowel verweerder (en zijn collega) als het $G$ en de producent van de zaag aansprakelijk gesteld voor de door haar geleden materiele en immateriële schade. Verweerder (en zijn collega) wordt in deze kwestie namens zijn aansprakelijkheidsverzekeraar bijgestaan door N. Aansprakelijkheid van verweerder (en zijn collega) is in eerste instantie van de hand gewe- 
zen omdat de aansprakelijkheid zou berusten bij I als producent van de zaag en/of het $\mathrm{G}$ als bezitter/ eigenaar van de zaag. Dit was voor klaagster reden om de onderhavige tuchtprocedure te starten.

$2.11 \mathrm{Na}$ de openbare terechtzitting van 31 januari 2017 - waarin de verdere behandeling van de tuchtklacht is aangehouden in afwachting van een eventuele minnelijke regeling - is op 3 februari 2017 door $\mathrm{N}$ namens verweerder (en zijn collega) alsnog aansprakelijkheid erkend voor de door klaagster als gevolg van de brandwond geleden schade.

2.12 Vervolgens is er tussen klaagster (en haar belangenbehartiger) en $\mathrm{N}$ (opnieuw) discussie ontstaan over de hoogte van de schade. Klaagster heeft zich in een (emotioneel) e-mailbericht van 24 februari 2017 tot (onder meer) verweerder gewend en aandacht gevraagd voor haar lichamelijke, emotionele en financiële problemen als gevolg van het incident. In dit bericht heeft zij aangedrongen op een spoedige financiële afwikkeling nu aansprakelijkheid is erkend. In zijn reactie van 26 februari 2017 schrijft de collega van verweerder mede namens verweerder:

'Uw email van 24 februari jl. heeft $C$ en mij bereikt en heeft grote indruk gemaakt. Naar aanleiding van uw email zijn wij een standpunt aan het formuleren betreffende de, in onze ogen incorrecte, werkwijze van de $\mathrm{N}$ in deze. Mogelijk kan dat $\mathfrak{u}$ helpen om het, door $\mathfrak{u}$ gewenste, doel te bereiken van een reële schadevergoeding (en daarmee uiteraard ook het intrekken van uw klacht tegen ons bij het tuchtcollege).

Wij willen dit standpunt echter eerst voorleggen aan mijn raadsvrouwe (mr. Berkhoff), zij is echter $\mathrm{t} / \mathrm{m} 3$ maart afwezig en verzoekt $\mathrm{u}$ derhalve ons tot 10 maart de tijd te geven dit af te ronden en met $u$ te delen.'

In een vervolgbericht van 10 maart 2017 schrijft de collega van verweerder:
'In ons mailbericht van 26 februari zegden wij $\mathrm{u}$ toe om $\mathrm{u}$ voor 10 maart nog een bericht te sturen.

Wij hebben inmiddels vernomen dat $\mathrm{N}$ een aanbod heeft gedaan richting uw gemachtigde. Omdat wij geen partij zijn in de onderhandelingen tussen $\mathrm{N}$ en uw gemachtigde kunnen wij daar verder ook geen uitspraak over doen. Uiteraard hopen wij van harte dat jullie tot overeenstemming kunnen komen en dat $\mathrm{u}$ daarmee deze vreselijke periode uit uw leven kunt afsluiten. Ook wij zullen het gebeuren levenslang met ons meedragen.'

2.13 Ten tijde van de (voortgezette) behandeling op de openbare zitting van 19 mei 2017 was de civiele aansprakelijkheidskwestie nog niet afgewikkeld.

\section{De klacht en het standpunt van klaagster}

De klacht houdt zakelijk weergegeven in dat verweerder onzorgvuldig heeft gehandeld door:

(i) de oscillerende zaag in strijd met de gebruiksaanwijzing tijdens de operatie op het bovenbeen van klaagster neer te leggen, als gevolg waarvan een ernstige brandwond is ontstaan;

(ii) na het incident geen contact met klaagster op te nemen om te informeren naar haar toestand; en

(iii) aansprakelijkheid van de hand te wijzen en de fabrikant aan te wijzen als schuldige.

\section{Het standpunt van verweerder}

Verweerder heeft zich bij monde van mr. BerkhoffMuntinga ter zitting op 19 mei 2017 primair beroepen op de niet-ontvankelijkheid van klaagster omdat - nu op 3 februari 2017 alsnog (civiele) aansprakelijkheid is erkend - sprake zou zijn van oneigenlijk gebruik van de tuchtprocedure en subsidiair de klacht en de daaraan ten grondslag gelegde stellingen bestreden. Voor zover nodig wordt daarop hieronder ingegaan. 


\section{De beoordeling}

\section{Ontvankelijkheid}

5.1. Het College verwerpt het beroep van verweerder op de niet-ontvankelijkheid van klaagster in haar klacht. Het feit dat aansprakelijkheid voor het handelen van verweerder (en zijn collega) voor de door klaagster als gevolg van de brandwond geleden schade inmiddels is erkend, betekent geenszins dat door het desondanks voortzetten van de onderhavige tuchtprocedure, sprake zou zijn van oneigenlijk gebruik van de tuchtprocedure. Het College heeft zich - in het licht van het feit dat de onderhavige tuchtprocedure kennelijk nodig was om erkenning van aansprakelijkheid af te kunnen dwingen ook enigszins over dit verweer verbaasd. Het staat klaagster vrij om het handelen van verweerder ter tuchtrechtelijke toetsing aan het College voor te leggen. Een eventueel civiel aansprakelijkheidstraject (en het verloop daarvan) doet daar niet aan af. Daarom zal nu inhoudelijk op de klachtonderdelen worden ingegaan.

\section{Klachtonderdeel 1}

5.2. Met betrekking tot het gebruik van de oscillerende zaag staat vast dat de gebruiksaanwijzing van deze zaag het voorschrift bevat dat de zaag niet op de patiënt mag worden geplaatst om brandwonden bij de patiënt te voorkomen. In dat kader acht het College het niet zo relevant of het een in de orthopedische praktijk al dan niet gebruikelijke gang van zaken is dat een dergelijke zaag - ondanks dat deze kan worden afgekoppeld - in het operatiegebied (op operatietafel of op de (afgedekte) patiënt) wordt gelegd als deze gedurende de operatie even niet wordt gebruikt, maar daarna nog wel nodig is. Als een dergelijke gang van zaken al gebruikelijk zou zijn, moet op basis van voornoemde gebruiksaanwijzing worden vastgesteld dat dit een onjuiste gang van zaken is die aanzienlijke risico's voor patiënten met zich meebrengt, welke risico's zich ten aanzien van klaagster helaas ook hebben verwezenlijkt.

5.3 Dat het in de praktijk kennelijk niet gebruikelijk is dat de gebruiksaanwijzing van dit soort 'simpele' apparaten wordt gelezen, zoals verweerder naar voren heeft gebracht, wil niet zeggen dat verweerder in dit kader dus geen tuchtrechtelijk verwijt kan worden gemaakt. Als artsen gebruik maken van technische hulpmiddelen, behoren zij zich te vergewissen van de werking van deze hulpmiddelen en eventuele daaraan verbonden risico's / gevaren, bijvoorbeeld door het lezen van de gebruikershandleiding van dergelijke hulpmiddelen. Anders dan verweerder heeft betoogd, mogen artsen daarbij niet enkel varen op hetgeen zij tijdens hun opleiding hebben geleerd over het gebruik van dergelijke apparaten. De tijdens de opleiding opgedane kennis kan in de praktijk zijn verouderd en - zoals de onderhavige zaak illustreert - kan een in de opleiding aangeleerde werkwijze bovendien in strijd zijn met de aan het gebruik van een technisch hulpmiddel verbonden veiligheidsvoorschriften.

5.4 Door de oscillerende zaag in strijd met de gebruiksaanwijzing op het been van klaagster te leggen, heeft verweerder in strijd gehandeld met de van hem ten opzichte van klaagster te verwachten zorgvuldigheid.

\section{Klachtonderdeel 2}

$5.5 \mathrm{Na}$ een ernstig incident als het onderhavige is het van belang dat hier door de betrokken zorgverleners adequaat op wordt gereageerd en voldoende nazorg wordt geboden. In dit kader kan worden gewezen op de sinds 2010 geldende Gedragscode Openheid medische incidenten; betere afwikkeling Medische Aansprakelijkheid (GOMA) waarin onder meer is opgenomen dat als er zich een incident heeft voorgedaan met (mogelijke) gevolgen voor de patiënt, zo snel mogelijk contact wordt opgenomen met de patiënt (Aanbeveling 3), er wordt ondernomen wat nodig is om de negatieve gevolgen van het incident voor de gezondheidssituatie weg te nemen of te beperken (Aanbeveling 4), wordt onderzocht hoe het incident heeft kunnen ontstaan en activiteiten worden ondernemen die nodig zijn om te voorkomen dat het incident zich nog eens voordoet (Aanbeveling 5) en als blijkt dat er sprake is van een fout, die door de betreffende zorgaanbieder / zorgverlener(s) wordt erkend en daarvoor verontschuldigingen worden aangeboden. Deze uitgangspunten zijn 
- weliswaar in iets andere bewoordingen - sinds 1 januari 2016 ook vastgelegd in artikel 10 lid 3 van de Wet kwaliteit, klachten en geschillen zorg (Wkkgz).

5.6 Door direct na het incident de aanwezige plastisch chirurg in consult te roepen (die de behandeling van de brandwond in eerste instantie verder op zich genomen heeft) en klaagster en haar partner op de verkoeverkamer direct op de hoogte te brengen van het incident en daarvoor excuses te maken, heeft verweerder in beginsel adequaat op het incident gereageerd (zie hierna ook de beoordeling van klachtonderdeel 3). Door bovendien maatregelen te treffen om zo veel als mogelijk te voorkomen dat dergelijke incidenten zich in de toekomst nogmaals voor kunnen doen, en hierover een wetenschappelijk artikel te schrijven, heeft verweerder zich ook in dat kader voldoende ingespannen.

5.7 Klaagster verwijt verweerder weliswaar dat hij na het incident geen contact meer met haar heeft opgenomen om te informeren naar haar (gezondheids)toestand, maar klaagster heeft niet bestreden dat er na het incident wel degelijk een aantal maal contact met verweerder (en zijn collega) is geweest, onder andere in de vorm van poliklinische controleafspraken. Het College acht het voor de hand liggend dat er op die momenten door verweerder (en zijn collega) ook naar de gezondheidstoestand van klaagster is geïnformeerd. $\mathrm{Nu}$ verdere behandeling van zowel de brandwond als de linkervoet op verzoek van klaagster elders heeft plaatsgevonden, kon niet van verweerder worden verwacht dat hij ook na beëindiging van de behandeling nog actief contact met verweerster zou zoeken. Er is ook niet gebleken dat klaagster aan verweerder heeft laten weten daar behoefte aan te hebben. Het tweede klachtonderdeel is derhalve ongegrond.

\section{Klachtonderdeel 3}

5.8 Tot slot verwijt klaagster verweerder dat hij aansprakelijkheid van de hand bleef wijzen en de fabrikant aanwijst als schuldige. Aan verweerder kan worden toegegeven dat de beoordeling van de (civielrechtelijke) aansprakelijkheid (over het algemeen) namens de zorgaanbieder door zijn aanspra- kelijkheidsverzekeraar wordt uitgevoerd, en zorgverleners zich in die verhouding niet behoren uit te laten over aansprakelijkheid. De erkenning van aansprakelijkheid staat echter niet gelijk aan het erkennen van een fout (welk onderscheid voor klaagster begrijpelijkerwijs moeilijk te maken is), hetgeen juist wel tot het domein van de zorgverlener behoort.

5.9 Verweerder (en zijn collega) hebben na het incident weliswaar hun excuses aangeboden, maar niet is gebleken dat zij hun fout ook hebben erkend. $\mathrm{Nu}$ het in strijd met de gebruiksaanwijzing hanteren van een oscillerende zaag als gevolg waarvan er een ernstige brandwond bij klaagster is ontstaan, naar het oordeel van het College echter moeilijk anders gekwalificeerd kan worden dan als een fout, had het op de weg van verweerder gelegen dit ten opzichte van verweerster ook toe te geven. Nu de klacht van verweerster echter betrekking lijkt te hebben op de erkenning van de aansprakelijkheid in het kader van de civiele schadeafwikkeling - het domein van de aansprakelijkheidsverzekeraar - kan verweerder hiervan tuchtrechtelijk geen verwijt worden gemaakt.

5.10 Het standpunt dat verweerder niet betrokken is geweest bij het civiele aansprakelijkheidstraject en de discussie daaromtrent, en hem daarvan derhalve geen enkel verwijt kan worden gemaakt, acht het College in zijn algemeenheid overigens niet juist. Als een zorgverlener een fout maakt - of een dergelijke fout door een patiënt wordt gesteld - laat de zorgverlener de civiele schadeafwikkeling van die fout doorgaans over aan zijn aansprakelijkheidsverzekeraar. Dit brengt naar het oordeel van het College echter niet mee dat de zorgverlener daarmee ook geen enkele verantwoordelijkheid meer zou dragen voor de manier waarop die schadeafwikkeling verloopt.

5.11 Ondanks dat het College niet over alle informatie met betrekking tot de civiele schadeafwikkeling in deze zaak beschikt, is zij er op basis van de beschikbare informatie en de verklaringen van partijen ter zitting voldoende van overtuigd geraakt dat de schadeafwikkeling in deze zaak door $\mathrm{N}$ niet op zorgvuldige wijze plaatsvindt. Illustratief hiervoor is 
dat de onderhavige tuchtprocedure noodzakelijk was om erkenning van aansprakelijkheid af te dwingen en - desondanks - door N, naast een (lang voor deze tuchtprocedure) reeds betaald voorschot, nog geen aanvullend voorschot / aanvullende schadevergoeding is uitgekeerd, in ieder geval tot het bedrag waarover tussen partijen geen discussie bestaat. Het uitblijven daarvan lijkt mede het gevolg te zijn van een discussie tussen de belangenbehartiger van klaagster en $\mathrm{N}$ over de buitengerechtelijke kosten (waar klaagster in principe buiten staat). De handelwijze van $\mathrm{N}$ is op verschillende punten in strijd met de aanbevelingen in de GOMA omtrent een adequate afhandeling van verzoeken om schadevergoeding. Bovendien spreekt ook de collega van verweerder in zijn bericht aan klaagster van 26 februari 2017 van een in hun ogen incorrecte werkwijze van $\mathrm{N}$ en heeft verweerder in zijn verweerschrift aangegeven dat hij zich de irritatie van patiënte gedurende de schadeafwikkeling met $\mathrm{N}$ wel voor kan stellen omdat hij het volledig met haar eens is dat zij zich over de aansprakelijkheidsvraag in deze eigenlijk helemaal niet zou hoeven buigen. Dit in civiele medische aansprakelijkheidszaken niet onbekende verschijnsel dat het patiënten onevenredig veel tijd, vechtlust, geld en aandacht kost om hun schade vergoed te kunnen krijgen (hetgeen lang niet ieder slachtoffer van een medische fout op kan brengen), acht het College verwerpelijk.

5.12 De zorgvuldigheid die een zorgverlener op grond van artikel 47 lid 1 Wet BIG jegens de patiënt moet betrachten, omvat eveneens de manier waarop de zorgverlener na een (gestelde) medische fout met de patiënt omgaat. Als er zich in het kader van de zorgverlening een incident voordoet, is communicatie, persoonlijke aandacht, empathie, zorgzaamheid en correcte bejegening van groot belang Niet valt in te zien waarom dit voor de financiële afwikkeling van een (verwijtbaar) incident anders zou zijn dan voor de medische afwikkeling daarvan. Ook niet als de financiële gevolgen namens de zorgverlener worden afgewikkeld door een aansprakelijkheidsverzekeraar. Op het moment dat een aansprakelijkheidsverzekeraar de schade op onzorgvuldige wijze afwikkelt (waarvan op basis van weten- schappelijk onderzoek inmiddels voldoende vaststaat dat dit een negatieve invloed heeft op het welzijn van patiënten), ligt het op de weg van de arts (wiens doel juist het bevorderen van het welzijn van patiënten zou moeten zijn) zijn verzekeraar daarop aan te spreken. Dit geldt in nog sterkere mate voor de zorgverlener die - zoals verweerder in deze zaak - tevens deel uitmaakt van de directie van de zorgaanbieder in kwestie. De aansprakelijkheidsverzekeraar zal op basis van de verzekeringsovereenkomst jegens de arts/zorgaanbieder immers verplicht zijn de schadeafwikkeling namens de arts op correcte wijze uit te voeren. Blijkens het bericht van zijn collega aan klaagster van 26 februari 2017 (zie hiervoor onder 2.12), heeft verweerder $\mathrm{N}$ na aanvang van de onderhavige tuchtprocedure wel op de in zijn ogen incorrecte werkwijze aangesproken. Het is echter onduidelijk of dit enig effect heeft gehad en bovendien had het op de weg van verweerder gelegen dat (veel) eerder te doen.

$5.13 \mathrm{Nu}$ het College met het voorgaande een vrij ruime uitleg heeft gegeven aan het derde klachtonderdeel - en de daarin vervatte norm, dat een hulpverlener niet enkel verantwoordelijk is voor een correcte afwikkeling van de medische gevolgen maar ook voor de financiële gevolgen van zijn fout, onder artsen mogelijk (nog) niet voldoende bekend is acht het College het nalaten van verweerder om $\mathrm{N}$ (tijdig) aan te spreken op de incorrecte wijze waarop de schade van klaagster werd (en mogelijk nog steeds wordt) afgewikkeld, op dit moment en in deze situatie niet tuchtrechtelijk verwijtbaar. Ook het derde klachtonderdeel is daarmee ongegrond.

De conclusie van het voorgaande is dat de klacht deels gegrond is. Verweerder heeft gehandeld in strijd met de zorg die hij ingevolge artikel 47 lid 1 van de Wet op de beroepen in de individuele gezondheidszorg jegens klaagster had behoren te betrachten.

Met betrekking tot de op te leggen maatregel overweegt het College dat verweerder zich ten tijde van het incident niet bewust was van het mogelijk onveilige karakter van de door de door hem gehanteerde werkwijze en hij bovendien lering heeft 
getrokken uit het incident. Er kan derhalve worden volstaan met een waarschuwing.

Om redenen, aan het algemeen belang ontleend, zal de beslissing zodra zij onherroepelijk is op na te melden wijze worden bekendgemaakt.

\section{De beslissing}

Het college:

- verklaart klachtonderdeel klachtonderdeel 1 gegrond;

- legt aan verweerder de maatregel van waarschuwing op;

- wijst de klacht voor het overige af.

\section{Noot}

\section{Inleiding}

In de gezondheidszorg is de laatste jaren veel aandacht voor de omgang met medische incidenten. Een belangrijke rol is hierbij weggelegd voor de Gedragscode Openheid medische incidenten; betere afwikkeling Medische Aansprakelijkheid (GOMA). Deze GOMA definieert een medisch incident als een onbedoelde gebeurtenis die tot schade aan de patient heeft geleid of nog kan leiden. De GOMA geeft richtlijnen voor enerzijds een adequate reactie op het incident (Deel A) en anderzijds een adequate reactie op verzoeken om schadevergoeding (Deel B). De financiële afwikkeling van zo'n verzoek ligt in de regel in handen van de medische aansprakelijkheidsverzekeraar, maar wat als deze verzekeraar de schaderegeling niet adequaat ter hand neemt? Draagt de zorgverlener ook voor dit aspect van de afwikkeling verantwoordelijkheid en kan hij hiervoor tuchtrechtelijk worden aangesproken? Deze vragen werden recentelijk voorgelegd aan het Regionaal Tuchtcollege voor de Gezondheidszorg te Amsterdam (hierna: het tuchtcollege) en bevestigend beantwoord. In de hier te bespreken uitspraken heeft het tuchtcollege ook naar eigen zeggen, 'een vrij ruime uitleg' gegeven aan de zorgplicht die ingevolge artikel 47 lid 1 Wet BIG op de zorgverlener rust. In deze annotatie volgt een bespreking van dit oordeel, waarbij ook de civielrechtelijke inbedding van deze extensieve zorgplicht van zorgverleners aan de orde komt.

\section{De operatieve ingreep}

Aan beide uitspraken ligt dezelfde casus ten grondslag. Klaagster werd door een orthopedisch chirurg (zaak ECLI:NL:TGZRAMS:2017:77) behandeld in verband met (pijn)klachten aan haar linkervoet en is op 16 mei 2014 aan deze voet geopereerd door de orthopedisch chirurg en zijn collega (zaak ECLI:NL:TGZRAMS:2017:78). Een van de operatieve handelingen betrof het verwijderen van overtollig botweefsel. Daarbij werd gebruik gemaakt van een oscillerende zaag. Op enig moment heeft een van beide orthopedisch-chirurgen de zaag op het linkerbovenbeen van klaagster gelegd. Een technisch mankement in de zaag veroorzaakte echter oververhitting als gevolg waarvan een derdegraads brandwond op het been is ontstaan. Zodra dit werd opgemerkt, is de brandwond gekoeld en behandeld. De beide chirurgen hebben de patiënt en haar partner op de verkoeverkamer op de hoogte gebracht van wat er gebeurd was. De verdere behandeling van de brandwond is overgedragen aan een plastisch chirurg van een andere kliniek. In dat behandelingstraject heeft klaagster nog eens twee operaties moeten ondergaan.

\section{Klachten en aansprakelijkstelling}

De patiënte heeft een klacht ingediend bij 'de M' (mogelijk wordt gedoeld op een klachtenfunctionaris, die sinds 2016 (dus na het onderhavige incident) een wettelijke basis heeft in art. $15 \mathrm{Wkkgz}$ ) waarbij de kliniek van verweerders is aangesloten. Deze klacht is gegrond bevonden ten aanzien van het ontstaan van de brandwond. Zij heeft daarnaast zowel verweerders als de producent van de zaag (civielrechtelijk) aansprakelijk gesteld voor de gevolgen van dit incident. De verzekeraar van verweerders heeft in eerste instantie aansprakelijkheid van de hand gewezen, stellende dat niet verweerders, maar de producent van de zaag aansprakelijk is. Deze afwijzende reactie was voor de patiënte aanleiding om een tuchtprocedure bij het Regionaal Tuchtcol- 
lege te beginnen. In deze tuchtprocedure is op 31 januari 2017 een zitting gehouden. De verdere behandeling is daarna aangehouden opdat partijen een minnelijke regeling konden beproeven. De aansprakelijkheidsverzekeraar (in de persoon van ' $\mathrm{N}$ ') heeft daarna alsnog aansprakelijkheid erkend.

Tot een vlotte schadeafwikkeling is het vervolgens kennelijk niet gekomen. Tussen (de belangenbehartiger van) de patiënte en $\mathrm{N}$ is discussie ontstaan over de hoogte van de schade en dat bracht de patiënte ertoe om een e-mail aan de orthopedisch chirurgen te sturen, waarin zij haar beklag doet over de wijze waarop $\mathrm{N}$ de schade afwikkelt. In hun antwoord hebben de orthopedisch chirurgen aangegeven zich (mede vanwege afwezigheid van hun raadsvrouwe) nog te beraden op hun standpunt in dezen. Zij gaven echter wel aan dat zij de werkwijze van $\mathrm{N}$ incorrect achtten. Enkele weken later - het is dan 10 maart 2017 - lieten zij aan de patiënte het volgende weten:

'Wij hebben inmiddels vernomen dat $\mathrm{N}$ een aanbod heeft gedaan richting uw gemachtigde. Omdat wij geen partij zijn in de onderhandelingen tussen $\mathrm{N}$ en uw gemachtigde kunnen wij daar verder ook geen uitspraak over doen. Uiteraard hopen wij van harte dat jullie tot overeenstemming kunnen komen en dat $\mathrm{u}$ daarmee deze vreselijke periode uit uw leven kunt afsluiten. Ook wij zullen het gebeuren levenslang met ons meedragen.'

De tuchtzaak is voortgezet en in dat kader heeft op 19 mei 2017 een mondelinge behandeling plaatsgevonden. Op dat moment was de civielrechtelijke kwestie nog niet afgerond.

\section{Deklachten}

De artsen hebben, aldus klaagster, op drie fronten onzorgvuldig gehandeld, namelijk door:

1 de oscillerende zaag in strijd met de gebruiksaanwijzing tijdens de operatie op het bovenbeen van klaagster neer te leggen, als gevolg waarvan een ernstige brandwond is ontstaan;
2 na het incident geen contact met klaagster op te nemen om te informeren naar haar toestand; en

3 aansprakelijkheid van de hand te wijzen en de fabrikant aan te wijzen als schuldige.

Zoals in de inleiding werd aangekondigd, concentreert deze annotatie zich op het oordeel van het tuchtcollege ten aanzien van de derde klacht: de civielrechtelijke afwikkeling. Met haar derde klacht verwijt patiënte de artsen dat zij (bij monde van N) aansprakelijkheid van de hand hebben gewezen en daarvoor naar de producent verwezen. Bij de behandeling van deze klacht maakt het tuchtcollege in overweging 5.9 eerst onderscheid tussen erkenning van aansprakelijkheid, hetgeen tot het domein van de aansprakelijkheidsverzekeraar behoort, en erkenning van de fout, hetgeen tot het domein van de zorgverlener behoort. Het college merkt op dat de artsen weliswaar excuses hebben aangeboden, maar dat de fout als zodanig (want zo kwalificeert het college dit medische incident inderdaad) niet is erkend. Het college vervolgt dat de klacht echter niet ziet op erkenning van de fout, maar op de civielrechtelijke aansprakelijkheid. Hierover kan het tuchtcollege zich echter niet uitlaten, omdat dit binnen het domein van de aansprakelijkheidsverzekeraar valt. In enkele aanvullende overwegingen (5.10 e.v.) gaat het college vervolgens wel uitgebreid in op de verantwoordelijkheid van de arts met betrekking tot die civielrechtelijke afwikkeling en op de tuchtrechtelijke toetsbaarheid daarvan. En juist in deze overwegingen ligt het belang van deze uitspraken, want daarin wordt - zoals het college zelf opmerkt - een 'vrij ruime uitleg' gegeven van de in artikel 47 lid 1 Wet BIG vervatte norm inzake de op de zorgverlener rustende zorgplicht. Het tuchtcollege overweegt namelijk het volgende:

'5.12 De zorgvuldigheid die een zorgverlener op grond van artikel 47 lid 1 Wet BIG jegens de patiënt moet betrachten, omvat eveneens de manier waarop de zorgverlener na een (gestelde) medische fout met de patiënt omgaat. Als er zich in het kader van de zorgverlening een incident voordoet, is communicatie, 
persoonlijke aandacht, empathie, zorgzaamheid en correcte bejegening van groot belang. Niet valt in te zien waarom dit voor de financiele afwikkeling van een (verwijtbaar) incident anders zou zijn dan voor de medische afwikkeling daarvan. Ook niet als de financiële gevolgen namens de zorgverlener worden afgewikkeld door een aansprakelijkheidsverzekeraar. Op het moment dat een aansprakelijkheidsverzekeraar de schade op onzorgvuldige wijze afwikkelt (waarvan op basis van wetenschappelijk onderzoek inmiddels voldoende vaststaat dat dit een negatieve invloed heeft op het welzijn van patiënten), ligt het op de weg van de arts (wiens doel juist het bevorderen van het welzijn van patiënten zou moeten zijn) zijn verzekeraar daarop aan te spreken.'

Deze overwegingen leiden overigens niet tot gegrondbevinding van de klacht, zo blijkt uit overweging 5.13:

' $\mathrm{Nu}$ het College met het voorgaande een vrij ruime uitleg heeft gegeven aan het derde klachtonderdeel - en de daarin vervatte norm, dat een hulpverlener niet enkel verantwoordelijk is voor een correcte afwikkeling van de medische gevolgen maar ook voor de financiële gevolgen van zijn fout, onder artsen mogelijk (nog) niet voldoende bekend is - acht het College het nalaten van verweerder om $\mathrm{N}$ (tijdig) aan te spreken op de incorrecte wijze waarop de schade van klaagster werd (en mogelijk nog steeds wordt) afgewikkeld, op dit moment en in deze situatie niet tuchtrechtelijk verwijtbaar.'

De betrokken artsen valt op dit punt dus geen tuchtrechtelijke maatregel ten deel. Maar het tuchtcollege heeft met deze uitspraken wel een stevig signaal afgegeven aan de medische wereld. De boodschap luidt: Zorgverlener, $\mathrm{u}$ bent óók verantwoordelijk voor een adequate financiële afwikkeling, en dient indien nodig - uw aansprakelijkheidsverzekeraar hierop aan te spreken.

\section{Zorg voor correcte schadeafwikkeling; ook dát nog...??}

Dat de professionele (zorg)standaard zich uitstrekt tot een adequate reactie op een medisch incident, staat - ook in deze zaak - buiten kijf. Daar komt nu, met deze tuchtrechtelijke uitspraken, óók nog de verantwoordelijkheid voor de financiële afwikkeling bij. Ik kan mij de reacties van zorgverleners op deze uitspraken al voorstellen: 'Ook dát nog?!' De resultaten van onderzoeken naar de impact van medische incidenten op de betrokken zorgverlener (zie bijvoorbeeld E. van Gerwen, Health professionals as second victims of patient safety incidents, impact on functioning and wellbeing, diss. Leuven (2016)) doen namelijk vermoeden dat het leveren van de professioneel vereiste nazorg op zich al een aanzienlijke (mentale) inspanning vergt. De vraag rijst ook welke inspanning in dit kader van de zorgverlener verwacht wordt; dient hij het werk van zijn aansprakelijkheidsverzekeraar proactief in de gaten te houden, of wordt een actieve betrokkenheid pas verwacht als er signalen van onvrede van de zijde van de patiënt vernomen worden? En wat te denken van de inbedding van deze verantwoordelijkheid, betreffende een onderwerp dat inhoudelijk zo ver afstaat van de eigen professie, in de dagelijkse praktijkvoering?

Een andere voorstelbare reactie is dan ook: 'Maar daarvoor heb ik toch juist een aansprakelijkheidsverzekeraar?' Die gedachte klinkt door in een van de e-mailberichten van de artsen aan de patiënte, waarin zij schrijven: 'Omdat wij geen partij zijn in de onderhandelingen tussen $\mathrm{M}$ en uw gemachtigde kunnen wij daar verder ook geen uitspraak over doen.' Deze reactie is mijns inziens indicatief voor het algemeen heersende beeld over de verantwoordelijkheidsverdeling tussen de zorgverlener en de aansprakelijkheidsverzekeraar, waarbij onderscheid wordt gemaakt tussen - wat ik hier noem - de medische afwikkeling en de juridische afwikkeling van het incident. Dit onderscheid maakt ook het tuchtcollege, zoals blijkt uit overweging 5.9, waarin wordt opgemerkt dat klacht drie buiten zijn bevoegdheid als tuchtrechter valt. Dit onderscheid wordt overigens ook heel duidelijk zichtbaar in de GOMA. Deel A ('Een adequate reactie op inciden- 
ten') richt zich primair op de zorgaanbieder en ziet specifiek op wat van zorgverleners verwacht wordt in hun communicatie met patiënten zodra zich (mogelijk) een medisch incident heeft voorgedaan. Deel B draagt de titel 'Een adequate afhandeling van verzoeken om schadevergoeding' en richt zich primair tot (de schadebehandelaar van) de aansprakelijkheidsverzekeraar. Volgens het tuchtcollege ontslaat betrokkenheid van de aansprakelijkheidsverzekeraar de zorgverlener echter niet van zijn (professionele) verantwoordelijkheid, ook voor een adequate afwikkeling van een uit het medische incident voortvloeiende schadeclaim.

Deze uitspraak zal, verwacht ik, veel stof doen opwaaien in de zorgsector. In deze annotatie besteed ik aandacht aan de volgende vragen:

1 Welke aanknopingspunten zijn er om de financiële afwikkeling onder de tuchtrechtelijk gewaarborgde zorgplicht van de zorgverlener te brengen? (par. 6)

2 Hoe verhoudt deze tuchtrechtelijke verantwoordelijkheid zich tot de civielrechtelijke verantwoordelijkheid? (par. 7)

3 Wat betekent deze uitspraak in de (rechts)verhouding tussen de zorgverlener en zijn verzekeraar? (par. 8)

\section{Tuchtrechtelijke aansprakelijkheid voor niet- adequate financiële afwikkeling}

De toetssteen voor het regionale tuchtcollege gezondheidszorg ligt in artikel 47 Wet BIG. In dit artikel liggen twee toetsingsmaatstaven besloten. De eerste maatstaf (vervat in lid 1 onder a) ziet specifiek op behandeling conform de medische professionele standaard. De tweede (zie lid 1 onder b) heeft betrekking op overige gedragingen die niet specifiek op de geboden medische zorg zien, maar wel in strijd zijn met het belang van een goede uitoefening van individuele gezondheidszorg. Het tuchtcollege benoemt het niet met zoveel woorden, maar het komt mij voor dat de hier aan de orde zijnde verantwoordelijkheid in deze tweede categorie valt.

Het tuchtcollege geeft een aantal argumenten voor zijn beslissing dat de medische zorgplicht zich ook uitstrekt tot de financiële afwikkeling van een medisch incident. In overweging 5.12 wijst het tuchtcollege, ten eerste, erop dat uit wetenschappelijk onderzoek blijkt dat onzorgvuldige schadeafwikkeling negatieve invloed heeft op de gezondheidstoestand van het slachtoffer en hecht het tuchtcollege, ten tweede, belang aan het feit dat voor artsen het doel juist zou moeten zijn: het bevorderen van het welzijn van patiënten. In deze combinatie van factoren ligt, zo komt mij voor, een belangrijke reden voor het tuchtcollege om de zorg voor adequate financiële afwikkeling óók aan tuchtrechtelijke toetsing te onderwerpen.

Het tuchtcollege merkt zelf op dat deze extensieve interpretatie van de medische zorgplicht 'onder artsen mogelijk (nog) niet voldoende bekend is'. Het terloopse 'nog' in dit citaat verdient kort de aandacht, want dit suggereert dat deze norm reeds kenbaar in artikel 47 Wet BIG besloten lag. Bij goede bestudering van de GOMA lijkt dat inderdaad het geval te zijn. In de algemene toelichting staat het volgende:

'De zorgaanbieder heeft, voor zover dat in zijn vermogen ligt, de verantwoordelijkheid erop toe te zien dat een schadeclaim binnen een redelijke termijn wordt afgehandeld. En hij moet daarbij alles doen wat daaraan kan bijdragen (waaronder passend en voortvarend reageren op verzoeken van zijn verzekeraar om informatie of reactie). Op de verzekeraar rust de verantwoordelijkheid om een ingediende claim zorgvuldig en voortvarend te beoordelen en te behandelen.'

Deze gedeelde verantwoordelijkheid voor een voortvarende afwikkeling wordt opnieuw aangehaald in de toelichting op Regel 15, die luidt dat de verzekeraar binnen drie maanden een onderbouwd standpunt over de aansprakelijkheid dient in te nemen. De toelichting op deze regel vermeldt:

'Zowel de zorgaanbieder als diens aansprakelijkheidsverzekeraar dient zich ervoor in te spannen dat de aansprakelijkstelling voortvarend kan worden behandeld.' 
Van Dijk en Simons constateren ook 'dat naast aansprakelijkheidsverzekeraars ook zorgaanbieders met het onderschrijven van deze code expliciet erkennen dat er sprake is van een gedeelde verantwoordelijkheid voor de afhandeling van klachten en schadeclaims' (Chr.H. van Dijk en J.P.M. Simons, 'GOMA: Gedragscode Openheid medische incidenten; betere afwikkeling Medische Aansprakelijkheid', TVP 2010, p. 71, cursivering toegevoegd).

Toch kan ik mij voorstellen dat zorgverleners hun rol in dezen vooral betrekken op een voortvarende informatieverstrekking ten aanzien van de toedracht van het medische incident, teneinde tot een vlotte beoordeling van de aansprakelijkheid te komen. Afgaand op de algemene toelichting (zie m.n. de tweede zin van citaat uit de algemene toelichting) lijkt ook de GOMA op deze wijze van betrokkenheid betrekking te hebben. Het hier besproken oordeel van het tuchtcollege impliceert echter een verderstrekkende verantwoordelijkheid. Hoe verhoudt deze tuchtrechtelijke verantwoordelijkheid zich dan tot de civielrechtelijke verdeling van verantwoordelijkheden - en bijbehorende aansprakelijkheden? Die vraag komt in de volgende paragraaf aan bod.

\section{Civielrechtelijke verantwoordelijkheid voor correcte schadeafwikkeling}

Het tuchtcollege maakt in overweging 5.9 duidelijk dat het niet aan hem is om de opstelling van (de verzekeraar van) de artsen ten aanzien van de aansprakelijkheid tuchtrechtelijk te beoordelen. Zijn uitspraken bevatten desalniettemin allerlei 'haakjes' met de civielrechtelijke verhouding tussen de zorgverlener en zijn aansprakelijkheidsverzekeraar.

Bezien met een civielrechtelijke bril springt vooral in het oog dat de artsen, blijkens een van de e-mailberichten aan de patiënte, menen dat zij 'geen partij zijn' bij de discussie tussen de patiënte en $\mathrm{N}$ over de schadeafwikkeling. Dat zij dat in praktische zin zo ervaren wekt geen verbazing, aangezien de schadeafwikkeling in de praktijk inderdaad door de aansprakelijkheidsverzekeraar ter hand genomen wordt. Vergelijk in dit verband ook R.P. Wijne, Aansprakelijkheid voor zorggerelateerde schade; een onderzoek naar obstakels in het civiele aansprakelijkheidsrecht en alternatieven voor verhaal van zorggerelateerde schade, dissertatie Rotterdam, 2013, p. 54:

'De aansprakelijk gestelde arts of het aansprakelijk gestelde ziekenhuis zal de regie in het onderzoek naar de aansprakelijkheid veelal overlaten aan zijn beroepsaansprakelijkheidsverzekeraar en zich conformeren aan diens oordeel over het karakter van zijn handelen.'

In civielrechtelijk opzicht snijdt de opmerking dat de artsen bij deze discussie 'geen partij zijn' echter geen hout. Ook al wordt de schadeclaim afgewikkeld door de aansprakelijkheidsverzekeraar, het is nog altijd de aansprakelijkheidsrechtelijke verbintenis van de artsen jegens hun patiënten waaraan uitvoering gegeven wordt. Het oordeel van het tuchtcollege strookt met deze civielrechtelijke verhoudingen, alwaar het college onder 5.10 overweegt:

'dit [het feit dat de afwikkeling doorgaans aan de verzekeraar wordt overgelaten, FMRB] brengt naar het oordeel van het College echter niet mee dat de zorgverlener daarmee ook geen enkele verantwoordelijkheid meer zou dragen voor de manier waarop die schadeafwikkeling verloopt.'

In dit verband verdient vermelding dat deze aansprakelijkheidsrechtelijke verbintenis van de verzekerde jegens het slachtoffer (hier: de patiënte) weliswaar primair de daadwerkelijke vergoeding van schade betreft, maar alleszins verdedigbaar - zeker in letselschadezaken - is dat daaronder ook een adequate afwikkeling moet worden begrepen. Dit vloeit in algemene zin voort uit artikel 6:2 lid $1 \mathrm{BW}$, dat voorschrijft dat schuldeiser en schuldenaar zich conform de eisen van redelijkheid en billijkheid ten opzichte van elkaar behoren te gedragen. Voorts kan aangenomen worden dat in het proces van afwikkeling van een aansprakelijkheid scheppende gebeurtenis op de aansprakelijke partij (ook) de verplichting rust om verdere schade bij het slachtoffer te voorkomen (vergelijk S.D. Lindenbergh, Herstel bij 
letsel. Over juridische fundering van verplichtingen tot herstel in: G.R. de Groot e.a., Kritiek op recht - Liber Amicorum Gerrit van Maanen, Deventer: Kluwer 2014, par. 4). Zoals bekend kan een niet-adequate (of: onbetamelijke) wijze van afwikkeling tot verdere (gezondheids)schade bij het slachtoffer leiden. De beslissing in de hier besproken tuchtzaken kan ook tegen deze achtergrond worden begrepen.

Met (in ieder geval) de aansprakelijkheidsrechtelijke verbintenis tussen de zorgverlener en de patiënt als referentiekader, kwalificeren de in het kader van de schadeafwikkeling door de verzekeraar ontplooide activiteiten civielrechtelijk als vertegenwoordiging in de zin van artikel 3:60 BW. De verzekeraar geldt daarbij als vertegenwoordiger en de verzekerde als vertegenwoordigde. Bij de schadeafwikkeling geeft de verzekeraar in essentie uitvoering aan de op zijn verzekerde rustende schadevergoedingsplicht. In het verlengde daarvan heeft mijns inziens te gelden dat indien bij deze uitvoering onrechtmatig wordt gehandeld (in dit geval bestaande uit een onzorgvuldige wijze van schadeafwikkeling), artikel 6:76 BW aanknopingspunten biedt voor civielrechtelijke aansprakelijkheid van de verzekerde voor het handelen van zijn verzekeraar. Een dergelijke civielrechtelijke aansprakelijkheid van de arts, als verzekerde, voor 'onverkwikkelijke schadeafwikkeling' door zijn aansprakelijkheidsverzekeraar is reeds door diverse auteurs bepleit. Zie specifiek met betrekking tot medische aansprakelijkheidskwesties: J.L. Smeehuijzen, 'De verantwoordelijkheid van de arts voor schadeafwikkeling door zijn verzekeraar', TvGR 2009, nr. 3, p. 160-175.

De hier besproken tuchtrechtelijke uitspraken bieden evident steun voor deze opvatting. Zij bieden bovendien grond voor de gedachte dat in het geval van medische aansprakelijkheid zelfs artikel 6:171 BW als grondslag voor aansprakelijkheid kan gelden. Voor andersoortige letselschadezaken, bijvoorbeeld voor verkeerszaken, komt deze kwalitatieve aansprakelijkheidsgrond in beginsel niet voor toepassing in aanmerking. Een voorwaarde voor aansprakelijkheid voor fouten van een niet-ondergeschikte hulppersoon is immers dat de hulppersoon is ingeschakeld in het kader van de bedrijfsuitoefe- ning van de opdrachtgever. Een dergelijke inzet bij de uitoefening van het bedrijf is in de meeste aansprakelijkheidskwesties niet eenvoudig te construeren. Door de financiële afwikkeling nadrukkelijk onder de paraplu van de medische zorgplicht te brengen, wordt dit in het kader van medische aansprakelijkheidskwesties echter wel verdedigbaar. Als immers de medische zorgplicht van de arts zich ook uitstrekt tot een adequate financiële afwikkeling, gelden de hierop betrekking hebbende activiteiten van de medische aansprakelijkheidsverzekeraar dan wellicht als werkzaamheden, verricht 'ter uitoefening van diens bedrijf', als bedoeld in artikel 6:171 BW?

Hoe dat laatste ook zij, de interpretatie die het tuchtcollege vanuit het tuchtrechtelijke perspectief geeft aan de op de arts rustende zorgplicht past in beginsel goed in het civielrechtelijke kader. Bezien vanuit dat perspectief voert de verzekeraar namens de verzekerde de op laatstgenoemde rustende aansprakelijkheidsrechtelijke verbintenis uit. Deze verbintenis omvat mede een adequate afwikkeling van de schadevergoedingsplicht, conform de eisen van redelijkheid en billijkheid. In deze vertegenwoordigingsconstructie neemt de verzekeraar weliswaar het voortouw in de civielrechtelijke afwikkeling, maar dat ontslaat de aangesproken zorgverlener niet van de eigen verantwoordelijkheid die hij in verhouding tot de patiënt heeft voor een passende afwikkeling van de schadeclaim. Ingevolge artikel 6:76 BW (en wellicht ook art. 6:171 BW) kan in deze constructie ook aansprakelijkheid van de verzekerde zorgverlener worden aangenomen voor de (onbetamelijke) gedragingen van de verzekeraar, omdat de verzekeraar gekwalificeerd kan worden als (niet-ondergeschikte) hulppersoon in de zin van deze bepaling(en).

\section{Enkele vraagpunten ten aanzien van de civielrechtelijke verhouding tussen de zorgverlener en zijn verzekeraar}

$\mathrm{Nu}$ met deze uitspraken ook de financiële afwikkeling binnen de medische zorgplicht van de zorgverlener (art. 47 Wet BIG) wordt gebracht, rijst echter de vraag of de verzekeringsrechtelijke verhouding 
tussen de zorgverlener en de aansprakelijkheidsverzekeraar voldoende toegesneden is op deze extensieve verantwoordelijkheid. Met andere woorden: biedt de verzekeringsovereenkomst de zorgverlener voldoende handvatten om hieraan adequaat invulling te geven?

In dit verband wijs ik op overweging 5.12, waarin het tuchtcollege opmerkt dat '[d]e aansprakelijkheidsverzekeraar op basis van de verzekeringsovereenkomst jegens de arts immers verplicht [zal] zijn de schadeafwikkeling namens de arts op correcte wijze uit te voeren'. In civielrechtelijke termen: de verzekeraar die zich niet adequaat van deze taak kwijt, schiet jegens zijn verzekerde tekort in de nakoming van de verzekeringsovereenkomst. In het verlengde daarvan geldt dat de verzekerde op grond van die overeenkomst jegens de verzekeraar aanspraak mag maken op een passende wijze van schadeafwikkeling. Zo mag de verzekerde er, bijvoorbeeld, van uitgaan dat de verzekeraar daarbij de richtlijnen van de GOMA in acht neemt. De verzekerde heeft daar ook belang bij, omdat hijzelf anders op zijn beurt tekortschiet in de op hem rustende verbintenis uit hoofde van aansprakelijkheid jegens de patiënte (zie hierboven).

De verzekeringsovereenkomst kan echter bepalingen bevatten die de zorgverlener (kunnen) belemmeren in het daadwerkelijk invulling geven aan de door het tuchtcollege aangenomen verantwoordelijkheid. De polisvoorwaarden van aansprakelijkheidsverzekeringen bepalen in de regel dat de schadeafwikkeling door de verzekeraar ter hand genomen wordt. Deze zogenoemde schaderegelingsclausules (P.M. Leerink, 'De aansprakelijkheidsverzekering' (par. 23.9.3), in: M.L. Hendrikse, Ph.H.J.G. van Huizen en J.G.J. Rinkes (red.), Verzekeringsrecht, vierde druk, Deventer: Kluwer 2015) zijn vanuit verzekeraarsperspectief goed te verklaren. De verzekeraar draagt immers de financiële last van aansprakelijkheid en heeft daarom een substantieel eigen belang bij de wijze waarop de schadeclaim wordt afgewikkeld. Bovendien ligt de juridische expertise die nodig is voor afwikkeling van letselschadezaken bij de verzekeraar; de zorgverlener is zelf onvoldoende toegerust om een medische aansprakelijkheids- kwestie eigenhandig af te wikkelen. Mede gelet op de schaderegelingsclausules zal diens betrokkenheid bij de civielrechtelijke kwestie daarom in de praktijk beperkt blijven tot het verstrekken van informatie over de toedracht van het medische incident. Op deze inbreng - informatievoorziening ter beoordeling van de aansprakelijkheidsvraag - lijken ook de GOMA-richtlijnen hoofdzakelijk betrekking te hebben (zie hiervoor, par. 7).

Maar deze inbreng is van een andere orde dan de betrokkenheid waartoe de recente uitspraken van het tuchtcollege nopen. De aangenomen verantwoordelijkheid voor de financiële afwikkeling vergt dat de zorgverlener over de schouder van de verzekeraar meekijkt en, zo nodig, de verzekeraar 'op de vingers tikt'. Dit aspect van de zorgplicht vraagt dus veel meer van de zorgverlener dan alleen (vlotte) informatieverstrekking. En het is maar de vraag of de zorgverlener daar in de praktijk aan kan voldoen. Bij gebrek aan juridische expertise kan het, ten eerste, voor de zorgverlener lastig zijn om de zorgvuldigheid van de aanpak van zijn verzekeraar op waarde te schatten. Om, waar nodig, passende maatregelen te treffen, zal de zorgverlener bovendien - en: op zijn minst - op de hoogte moeten zijn (of kunnen raken) van de wijze waarop zijn verzekeraar de schade afwikkelt. Met name op dit punt rijst de vraag of, en in hoeverre, de verzekeraar zijn verzekerde voldoende en tijdig informeert over het verloop van de schaderegeling. Op dit punt kan dus sprake zijn van informatiegebrek aan de zijde van de zorgverlener. Dit gebrek kan natuurlijk, zoals ook in de onderhavige zaak gebeurde, opgeheven worden door proactieve patiënten die hun artsen erop aanspreken dat hun verzekeraar 'niet thuis geeft', maar mogelijk zal niet iedere patiënt die stap zetten. Het ziet er dan ook naar uit dat de zorgverlener, om goed invulling te geven aan deze zorgplicht, actief (of: actiever dan nu gangbaar is) over de schouder van zijn verzekeraar zal moeten meekijken. In het verlengde hiervan rijst de vraag naar de houdbaarheid van de eerdergenoemde schaderegelingsclausules. Het effect van deze clausules is immers dat de verzekerde zorgverlener op afstand van het schaderegelingsproces staat en daarmee versterken deze 
schaderegelingsclausules het zojuist gesignaleerde (feitelijke) informatiegebrek. Daarom staan zij mijns inziens op gespannen voet met de thans aangenomen extensieve zorgplicht.

\section{Ter uitgeleide: verschuivingen in de verhouding} zorgverlener/verzekeraar?

Zoals het tuchtcollege onderkent, is met deze uitspraken een ruime uitleg gegeven aan de zorgplicht die ingevolge artikel 47 Wet BIG aan tuchtrechtelijke toetsing onderhevig is. Deze uitbreiding past, mijns inziens, wel in de civielrechtelijke verhoudingen tussen het slachtoffer en de aansprakelijke partij en de rol die de verzekeraar civielrechtelijk in het afwikkelingsproces inneemt. De huidige praktijk van afwikkeling van (medische) letselschadezaken laat echter een beeld zien dat niet goed strookt met deze extensieve zorgplicht. In de praktijk wordt de afwikkeling overgelaten aan de verzekeraar. De verzekeraar trekt de afhandeling ook nadrukkelijk naar zich toe. Wil de zorgverlener goed invulling kunnen geven aan dit aspect van zijn zorgplicht, dan is echter een nauwere betrokkenheid bij het werk van zijn aansprakelijkheidsverzekeraar vereist. Voor de individuele zorgverlener kan deze extensieve zorgplicht bezwarend zijn, niet in de laatste plaats omdat zo'n financieel afwikkelingstraject de zorgverlener wezensvreemd is. De tuchtrechtelijke toetsbaarheid kan echter óók een extra stimulans zijn voor de zorgsector in brede zin om zich in te spannen om 'verwerpelijke' (zie overweging 5.11) afwikkelingspraktijken van verzekeraars steeds verder terug te dringen. In het kader van de nagestreefde optimalisering van de afwikkeling van (medische) aansprakelijkheidszaken is dat aan te moedigen. In de praktijk zal hiervoor wel een zekere verschuiving in de onderlinge verhoudingen tussen de zorgverlener en zijn aansprakelijkheidsverzekeraar nodig zijn.

Mr. F.M. (Femke) Ruitenbeek-Bart is PhD candidate in private law, Erasmus School of Law 